\title{
MILESTONES IN THE HISTORY OF PEDIATRIC SURGERY DURING THE BYZANTINE TIMES
}

\author{
KLJUČNI DOGAĐAJI U POVIJESTI DJEČJE \\ KIRURGIJE ZA VRIJEME BIZANTA
}

\author{
Anastasia Oikonomou-Koutsiari", \\ Effie Poulakou-Rebelakou “*, Evangelos Menenakos***, \\ Epameinodas Koutsiaris ${ }^{* * * *}$, Georgios Zografos ${ }^{* * * *}$
}

\begin{abstract}
Summary
During the Byzantine Times, medicine and surgery developed as Greek physicians continued to practice in Constantinople. Healing methods were common for both adults and children, and pediatrics as a medical specialty did not exist.

Already Byzantine hospitals became institutions to dispense medical services, rather than shelters for the homeless, which included doctors and nurses for those who suffered from the disease. A major improvement in the status of hospitals as medical centers took place in this period, and physicians were called archiatroi. Several sources prove that archiatroi were still functioning in the late sixth century and long afterward, but now as xenon doctors.

Patients were averse to surgery due to the incidence of complications. The hagiographical literature repeated allusions to doctors. Concerns about children with a surgical disease often led parents to seek miraculous healings achieved by Christian Protectors - Saints.

* Department of Pediatric Surgery, General Hospital of Larissa, Larissa, Greece.

** Department of History of Medicine, National \& Kapodistrian University of Athens, Athens, Greece.

*** First Pre-Educative Surgery Clinic, National \& Kapodistrian University of Athens, Athens, Greece.

**** Andrology Department of Volos, Volos, Greece.

Correspondence Address: Department of Pediatric Surgery, General Hospital of Larissa, Larissa, Greece, 16, Tsopotou St, Volos 38222, Greece.E-mail: paidoxeirourgiki@gmail.com.
\end{abstract}


This paper is focused on three eminent Byzantine physicians and surgeons, Oribasius, Aetius of Amida, Paul of Aegina, who dealt with pediatric operations and influenced the European Medicine for centuries to come.

We studied historical and theological sources in order to present a comprehensive picture of the curative techniques used for pediatric surgical diseases during the Byzantine Times.

Keywords: Byzantine History, pediatric surgery, Protectors-Saints

\section{INTRODUCTION}

Medical practice and surgery appear to have been highly developed during the Byzantine period. Hellenistic civilization dominated the Mediterranean world and survived the Byzantine Empire following the fall of Rome. Scientific thought during this period had evolved from medical knowledge of classical antiquity, enriched with new therapeutic modalities and medical terms, but also mixed with older traditions of folk medicine. Christian and Jewish physicians in Pergamum and Alexandria taught medicine and preserved the works of Galen and Hippocrates.

The practice of surgery, in particular, was developed owing to the advances in anatomic knowledge gained during the Hellenistic period when dissection of the human body was permitted. ${ }^{1}$ There was no specialty of pediatric surgery, and healing methods at that time were similar for adults and children. Patients often rejected surgical care because of the high rate of complications and doctor's excessive fees. Christians were often hostile to surgical treatments. In the literature, miracles are often placed in a position antagonistic to conventional medicine and are co-examined in the context of "folklore medical wisdom". ${ }^{2}$ Despite the fact that in later years the study of the lives of saints and their miracles has attracted the interest of historians, it is debatable whether their miracles could be considered as a specific therapeutic practice, entirely discrete from traditional "folklore medical wisdom".

This paper is focused on the eminent Byzantine physicians and surgeons, Oribasius, Aetius of Amida, Paul of Aegina, who dealt with pediatric operations.

Laskaratos, J.G., Tsiamis, C. \& Kostakis, A. (2003), Surgery for inguinal hernia in Byzantine times (A.D. 324-1453): first scientific descriptions, World Journal of Surgery, 27 (10), 1165-1169.

2 Mentis, A.F., Kararizou, E. (2011), The dialectic relationship between medicine and miracles in the Eastern Christian Roman Empire, Archives of Hellenic Medicine, 28(4), 561-568. 


\section{ByzANTINE SURGEONS AND PEDIATRIC SURGICAL DISEASES}

Oribasius (325-403 AD) was born in Pergamon, studied at Alexandria and in Constantinople. He became a court physician to Emperor Julian $(361-363$ AD), nephew of Constantine the Great. Oribasius had sound advice on the care of children and was among the most important medical writers of the Byzantine period. His 70-volume medical encyclopedia preserved the writings of many early physicians, whom he translated and excerpted with great care. The volume "Oribasii Sardiani Synopseos ad Eustathium", written for his son, demonstrates his clinical knowledge of childhood diseases, diet in pregnancy, and the choice of nurses for infants. He described three varieties of hydrocephalus: one with fluid between the scalp and the pericranium (probably a hematoma), one with fluid between the pericranium and cranium and another with fluid between the cranium and the cerebral membranes. ${ }^{3}$ He thought that hydrocephalus was caused by midwives who applied pressure on the baby's head during delivery. He suggested surgical intervention only under exceptional conditions but used palliative treatment to relieve the symptoms. ${ }^{4}$

Oribasius refers to penis disorders, hypospadias due to urethra damage, and epispadias recording the knowledge of the ancient Greek physicians Heliodorus (first century CE) and Antyllus (second century $\mathrm{CE}$ ). When the opening is

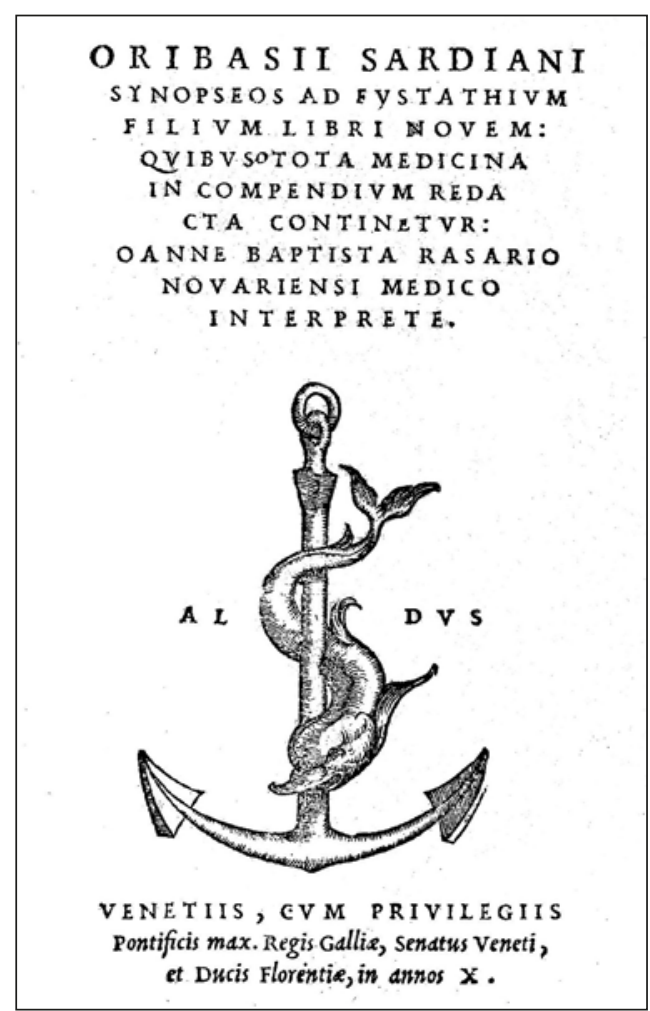

Figure I: "Oribasii Sardiani Synopseos ad Eustathium", I554.

\footnotetext{
Raffensperger, J.G. (2012), Children's Surgery: A Worldwide History, Jefferson / North Carolina; McFarland \& Company, 48.

4 Durmont, D.S. \& Smith, R.M. (1992c), Orivasios. Collectiones medicae, California; Thesaurus Linguae Greacae [CD ROM] CD ROM Musaios, Book 46, Chapter 28, Section 6.2 .
} 
near the base of the penis, it must be considered as incurable. Surgical cure is only possible if the opening is placed on the glans. The best, safest and simplest method, writes Oribasius, is the so-called aлоколиं (cutting the glans around the corona glandis with a smilion). According to Oribasius, phimosis is caused by the cicatrix of the prepuce or results from the increase of new flesh. ${ }^{5}$ The operation included straight incisions equally spaced at three or four points in the interior layer of the prepuce using a "phlebotome" (a fine sharp-pointed knife) or a "skolopion" (a type of long and slender cutting instrument). ${ }^{6} \mathrm{~A}$ tube of lead is placed between the prepuce and glans, wrapped with dry papyrus; then, the prepuce is drawn forward, over and around the papyrus. In this way, symphyses between the prepuce and glans are prevented; then the papyrus, absorbing the liquids, swells, increasing the space between prepuce and glans. ${ }^{7}$ The medical writer does not define the duration necessary for this treatment, but it can be supposed that the tube would have had to remain until complete healing. According to Oribasius, if the prepuce is retracted and cannot be moved to its original position, the disease is called "periphimosis" (today known as paraphimosis). ${ }^{8}$ If the situation persists, conservative treatment is useless. Oribasius recommended an operation to create symphysis. Referring to circumcision, he suggested removing the prepuce from the glans and dressing with water-cress and honey to stop the spread of ulcer and facilitate healing. ${ }^{9}$ A detailed description, unique in Byzantine bibliography, has survived in Oribasius texts, describing an operation for a scrotal hernia to preserve the testicles. ${ }^{10}$

In his chapter "On Imperforate Anus", he suggested a manipulation by hand to open the anus prior to surgery. ${ }^{11}$ This finger dilatation seems valid up until now, though, instead of hands, scalpel and special surgical retractors are used in order to achieve better control of the area for the detection

\footnotetext{
Raeder, I. (1933), Oribasii collectionum medicarum reliqviae, vol. IV, Lipsiae et Berolini; Teubner, 55-62.

6 Milne, J.S. (1976) Surgical instruments in Greek and Roman times, Chicago; Ares Publishers, 28-46, 94-7.

Raeder, I. (1933), 55-62.

Ibid., 55-62.

9 Lascaratos, J., Kostakopoulos, A. \& Louras, G. (1999), Penile surgical techniques described by Oribasius (4th century CE), British Journal of Urology, 84, 16-19.

10 Raeder, I. (1933), Oribasii collectionum medicarum reliquiae, vol. IV, Lipsiae et Berolini; Teubner, 55-62.

11 Tsoucalas, G., Gentimi, F., Kousoulis, A.A., Karamanou, M., \& Androutsos, G. (2012), Imperforate anus and perianal fistula in Ancient Greek medical writings, Annals of Gastroenterology, 25(3), 241-242.
} 
of the imperforate part, which may be behind the anal membrane or even higher. $^{12}$

The $15^{\text {th }}$ chapter of the $47^{\text {th }}$ book of Oribasius' work is devoted to finger abnormalities (i.e., polydactyly and syndactyly). It is named "On fingers incidents". In this regard, polydactyly emphasizes that "the excess can contain either only soft tissue or bone as well". His description of surgical treatment is also thorough. ${ }^{13}$

Aetius of Amida (527-565 AD), the first Greek physician to become a Christian, studied medicine in Alexandria and became the chief physician in the court of Emperor Justinian. In his encyclopedia, Aetius adopted the theories of Galen and provided further information from Aretaeus on hydrocephalus being detected by the liquid found in the baby's head. ${ }^{14} \mathrm{He}$ defined hydrocephalus etymologically, by combining the word "head" (in

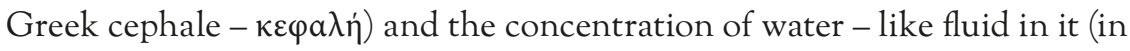
Greek ydor - v́ $\delta \omega \rho) .{ }^{15} \mathrm{He}$ suggested applying plasters consisting of old olive, salt, wax, dried pitini, root and peel of caper, the plants aristolochia, halvani (galvanon), and cress to the head of the sick child. ${ }^{16}$

For inguinal hernia, he was the first to describe the prolapsed peritoneum and cauterization of the groin ${ }^{17}$, and he also described umbilical hernia. ${ }^{18}$ Aetius of Amida treated perianal fistulas with the stone plaster of the Persians, the one called "tyrinis" and "pampathis". He also tried another technique, "the fresh urginea", like Asclepiades. He underlined: "In cases of fistulas with a narrow opening, having a placenta prepared in the shape of a worm (supposed to be a worm-shaped flexible tube), and after performing dilation and enema with mead or oenomel (wine and honey mixture), we inject the drug, cover with a plaster and swathe". ${ }^{19}$ In cases of anal fissures, he introduced a special cannula in the rectum greased with goose fat, the so-called "ihion". Modern conservative tech-

12 Grosfeld, J., O’Neill, J.A., Forkalsrud, E. \& Coran, A. (2006), Paediatric Surgery 6TH edition, Saint Louis; Mosby, 1597.

13 Papadakis, M., Manios, A., Trompoukis, C. (2019), Surgical treatment of polydactyly and syndactyly during the 4th century AD, Acta Chir Belg., 119(1), 64-65.

14 Durmont, D.S. \& Smith, R.M. (1992b²), Amideni Aetii. Iatricorum Liber, California; Thesaurus Linguae Greacae [CD ROM]. CD ROM Musaios, Book 15, Chapter 12, Section 26.

15 Lascaratos, J.G., Panourias, I.G., Sakas, D.E. (2004), Hydrocephalus according to Byzantine writers, Neurosurgery, 55(1), 214-20; discussion 220-1.

16 Durmont, D.S., \& Smith, R.M. (1992b $\left.{ }^{1}\right)$. Amideni Aetii. Iatricorum Liber, California; Thesaurus Linguae Greacae [CD ROM]. CD ROM Musaios, Book 15, Chapter 22, Section 14.

17 Zervos, S. (1909), Aetius, Iatricorum Liber XV, Athens; 21, 7-138.

18 Raffensperger, J.G. (2012), Children's Surgery: A Worldwide History, Jefferson / North Carolina; Mc Farland \& Company, 48.

19 Zervos, S. (1909), Aetius, Iatricorum Liber XV, Athens; 21, 7-138. 
niques resemble Aetius suggestions, even though substances, including fibrin glue injections, paraffin oils, nitroglycerin, and laxatives, have replaced his concoctions. ${ }^{20}$

Paul of Aegina (625-69o AD) was born on the island of Aegina and was one of the most prominent physician-writers of the Byzantine Empire. His work "Epitome of Medicine", comprised of 7 books, was a comprehensive compendium of the medical and surgical knowledge of his time and was subsequently translated into multiple languages. His work combined the ancient knowledge of Hippocrates, Galen, Oribasius, and the Alexandrians with contemporary medical observations. His work served as a bridge between Byzantine and Arabic medicine. He is considered to be one of the great ancient Greek medical writers; his work has influenced the subsequent evolution of Western European and Arab medicine. His writings on pediatrics followed Soranus and Oribasius. He devoted a special chapter "On imperfo-

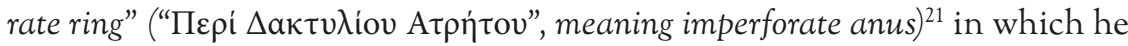
suggested opening up by hand prior to the surgical intervention. In cases of recurrence in infants, he recommended using a small lead tube until recovery: "In the infants whose ring does not have a natural opening, there is a probable blockage by a membrane. So, if possible, we open the membrane with our finger, or cut through with the edge of a small chisel, and treat the area with wine. In inadequately healed wounds in normally developed newborns, adhesions are frequently formed at the ring. We should have it broken with a suitable tool and place a lead tube or a small spike to the ring until perfect recovery". ${ }^{22}$ Contemporary practice loosely reminds one of Paul of Aegina's techniques; after the surgical procedure, reformation of the ring takes place, and dilations are performed using suppositories to prevent stenosis. Vaginal atresia was differentiated from an imperforate hymen, and after exploration, with a probe, he excised the membrane with a scalpel and packed the vagina. ${ }^{23}$

20 Grosfeld, J., O'Neill, J.A., Forkalsrud, E. \& Coran, A. (2006), Paediatric Surgery $6^{\text {th }}$ edition, Saint Louis; Mosby, 1597. / Grimaud, J.C., Munoz-Bongrand, N., Siproudhis, L. Abramowitz, L., Sénéjoux, A., Vitton, V., Gambiez, L., Flourié, B., Hébuterne, X., Louis, E., Coffin, B., De Parades, V., Savoye, G., Soulé, J.C., Bouhnik, Y., Colombel, J.F., Contou, J.F., François, Y., Mary, J.Y., Lémann, M. (2010), Fibrin glue is effective healing perianal fistulas in patients with Crohn's disease, Gastroenterology, 138, 2275-2281.

21 Pormann, P. (2004), The Oriental Tradition Paul of Aegina's Pragmateia, Oxford; Brill Academic.

22 Pormann, P. (2004), The Oriental Tradition Paul of Aegina's Pragmateia, Oxford; Brill Academic./Briau, R.M. (1855), Chirurgie de Paul d'Égine, Paris; Masson, 330-331.

23 Lascaratos, J.G., Panourias, I.G., Sakas, D.E. (2004), Hydrocephalus, according to Byzantine writers, Neurosurgery, 55(1), 214-20; discussion 220-1. 
Paul of Aegina distinguished the same types of hydrocephalus, as described by Oribasius and Aetius. In the third type, he described that the head is enlarged, there is pain, and the temple juts out; the patient's eyes become vacant with continual lacrimation. ${ }^{24} \mathrm{He}$ avoided surgery for hydrocephalus. ${ }^{25}$ However, when liquid appeared between the skin and the pericranium where the size of the swelling was small enough, he recommended one transverse incision. ${ }^{26}$

He distinguished between incomplete inguinal hernia (bubonocele) and the complete form (scrotal). ${ }^{27}$ Only for the latter, he recommended ligature of both sac and cord with amputation of the testicle. He described two techniques: I. "Open the hernia sac and reduce its content into the belly by invaginating it with a probe" 2. "Apply cauterization to the skin overlying the hernia aiming at scarring the overstretched peritoneum". ${ }^{28}$ It was Paul of Aegina who suggested a scientific approach to confront the failure of the two eyes to maintain proper alignment and work together as a team. Inside his third book, a fragment was written on the correction of strabismus. ${ }^{29} \mathrm{Paul}$ of Aegina proposed treatments of exotropia and endotropia, during infancy and for a toddler. He introduced an innovative method for the newborns to have a straight vision, "the congenital strabismus of the newborns must be treated with the placement of a facial mask (with 2 open holes in the middle axes of the eyes), so that the babies could only see in a straight line". ${ }^{30}$ For the complete correction, "A small oil lamp should be placed in the front line (nose-lamp straight line) in a way to prevent the lamp to illuminate of the wings". ${ }^{31}$ Although not even a diagram of the masks was saved until

24 Grosfeld, J., O'Neill, J.A., Forkalsrud, E. \& Coran, A. (2006), Paediatric Surgery $6^{\text {th }}$ edition, Saint Louis; Mosby, 1597.

25 Missios, S., Bekelis, K., Roberts, D. (2014) Neurosurgery in the Byzantine Empire: the contributions of Paul of Aegina (625-690 AD), J Neurosurg, 120, 244-249.

26 Durmont, D.S. \& Smith, RM. (1992a), Aeginitis P. Epitomae medicae libri septem, California; Thesaurus Linguae Greacae [CD ROM]. CD ROM Musaios, Book 6, Chapter 3, Section 26.

27 Read, R.C. (1984), The development of inguinal herniorrhaphy, Surgical Clinics of N. America, 64, 185-196.

28 Tsoucalas, G., Papaioannou, T., Karamanou, M. (2018), Michael Constantine Psellus (1020-1105 AD) and his definition of strabismus, Strabismus, 26(3), 155-157.

29 De Moulin, D. (1988), A history of Surgery, Dordrecht/ Boston/Lancaster; Martinus Nijhoff, 24.

30 Tsoucalas, G., Papaioannou, T., Karamanou, M. (2018), Michael Constantine Psellus (1020-1105 AD) and his definition of strabismus, Strabismus, 26(3), 155-157.

31 Tsoucalas, G. \& Sgantzos, M. (2016), Paul of Aegina (c. 625-690 AD), The Origins of the Early Correction of Pediatric Strabismus in Byzantine Empire, Strabismus, 24(3), 136-7. 
nowadays, Paul was the first to suggest the early correction of the eyes deviation and considered to be the father of orthoptics. ${ }^{32}$

The last of the Greek physicians was Paul of Aegina, who was practicing lithotomy in the Byzantine period. For lithotomy, he used a left-sided incision, as described by his predecessors. Celsus' description of lithotomy was similar to that described by Sushruta in ancient India. ${ }^{33}$ Sushruta was one of the first to describe lithotomy in great detail. ${ }^{34}$ Paul of Aegina recommended oblique perineal cystolithotomy mainly for those younger than 14 years old because the operation becomes more difficult as the patient's age increases. ${ }^{35}$ Tonsillectomy as well as direct laryngoscopy were known procedures in ancient Greece since the Hippocratic era. ${ }^{36}$ Paul of Aegina presented a surgical operation of the tonsils. With his forceps, he tried to completely remove each tonsil from the surrounding pharyngeal musculature, an innovative thought that laid the foundation for tonsil guillotine. His method "forceps-sunlight" (he stood next to the patient, and he used the sunlight as a surgical headlight) was a preclude toward the modern operating room. ${ }^{37}$

Inside his $7^{\text {th }}$ book treatise "Medical Compendium", Paul of Aegina dedicated a separate chapter, "On preternatural fingers and on persons having six fingers". He introduced a detailed description of the extremities' additional digits and proposed surgical removal and reconstruction of the additional digits. He marked the beginning of a new era for orthopedics. ${ }^{38} \mathrm{He}$ also made valuable contributions in the history of plastic surgery, as he described procedures varying from the treatment of nasal and jaw fractures to operations for gynecomastia and ganglion. ${ }^{39}$

32 Harley, R.D., Nelson, L.B., \& Olitsky, S.E. (2005), Harley's Pediatric Ophthalmology, Philadelphia; Lippincott Williams \& Wilkins, 553.

33 Shah, J., Whitfield, H.N. (2002), Urolithiasis through the ages, BJU Int., 89, 801-810.

34 Hernam, JR. (1915), Urology. A View Through the Retrospectoscope, Maryland: Harper \& Row.

35 Tsoucalas, I. (2004), Paediatrics From Antiquity Until the Modern Era, Athens, Greece: Science Press, 778-181.

36 Tsoucalas, G., Laios, K., Sgantzos, M., Androutsos, G. (2016), Paul of Aegina (c. 7th Century AD): Introducing in the Surgical Operating Theatre of the Era an Innovative Tonsillectomy with a Forceps Under the Sunlight, Surg Innov., 23(1), 102-3.

37 Tsoucalas, G., Sgantzos, M. (2017), Paul of Aegina (ca 625-690 AD), and his orthopedic surgical reconstruction of the preternatural fingers, Int Orthop., 41(1), 211-216.

38 Gurunluoglu, R., Gurunluoglu, A. (2001), Paulus Aegineta, a seventh-century encyclopedist and surgeon: his role in the history of plastic surgery, Plast Reconstr Surg., 108(7), 2072-9.

39 Papadakis, M., de Bree, E., Trompoukis, C., Manios, A. (2018), Paul of Aegina's surgical instruments: a complete surgical instrumentarium in the seventh century AD, ANZ J Surg, $88(7-8), 779-785$. 
The most exact description of the management of nasal fracture given by any physician of ancient times belongs to Paul of Aegina. Paul of Aegina's conservative and surgical management was adopted by later physicians. One hundred twenty-one different surgical instruments were identified and described in detail in the Epitome of Medicine. Thirty-three instruments $(27 \%)$ were exclusively reported by Paul of Aegina. ${ }^{40}$ Regarding the use of analgesics for the treatment of childhood diseases, in the Byzantine medical treatises, mekonion and opium are mentioned in the form of poultices, particularly for eye inflammations for both children and adults. ${ }^{41}$ Mandrake was not recommended as a children's analgesic. ${ }^{42}$ Most of the recipes of that period prescribed for severe pain, eye, and ear inflammation, cough, or fever included mainly opium and hyoscyamos in the form of paste or poultices for both children and adults. ${ }^{43}$ The health of children was consistently connected with their position in the Byzantine society. ${ }^{44}$ As the role of a child in the family was not essential, due to the high mortality from o to 5 years, the social position of the younger members was quite different from the contemporary situation. Although the upper class hired wet-nurses for breastfeeding and was taking care of the minor's health, surgical problems were unbearable, as anesthesia was lacking, and post-surgical infections were life-threatening factors.

\section{Protectors - SAints}

People always turned to the search for divine help during hard times of diseases, difficult or impossible to be treated by human medical knowledge.

It is not that Christianity was necessarily opposed to secular healing, but it presupposed an alternative medicine on which true Christians may be expected to rely. ${ }^{45}$

Christians embraced an ancient practice in the temples of Asclepius, called incubation, in order to reinforce the people's faith and convert new

40 Lascaratos, J., Lascaratos, G., Kostakopoulos, A. (2004), Surgical confrontation of urolithiasis in Byzantium, UROLOGY ELSEVIER INC, 63, 806-809.

41 Ramoutsaki, I.A., Dimitriou, E., \& Kalmanti, M. (2002), Management of childhood diseases in the Byzantine period: I - Analgesia, Pediatrics International, 44, 335-337. / Carter, A.J. (1996), Narcosis and nightshade, British Medical Journal, 313, 1630-1632.

42 Ramoutsaki, I.A., Dimitriou, E., \& Kalmanti, M. (2002).

43 Pedanii, Dioscorides (1958), De Materia Medica, $1^{\text {ST }}$ edition. Berlin; Max Wellmann.

44 Poulakou-Rebelakou, E. (2000), Pediatric practice during Byzantine times, Archives of Hellenic Medicine, 17(3), 326-331.

45 Nutton, V. (1984), From Galen to Alexander, Aspects of Medicine \& Medical Practice in Late Antiquity, Dumbarton Oaks Papers, (ed.) J. Scarborough, 38, 1-14. 


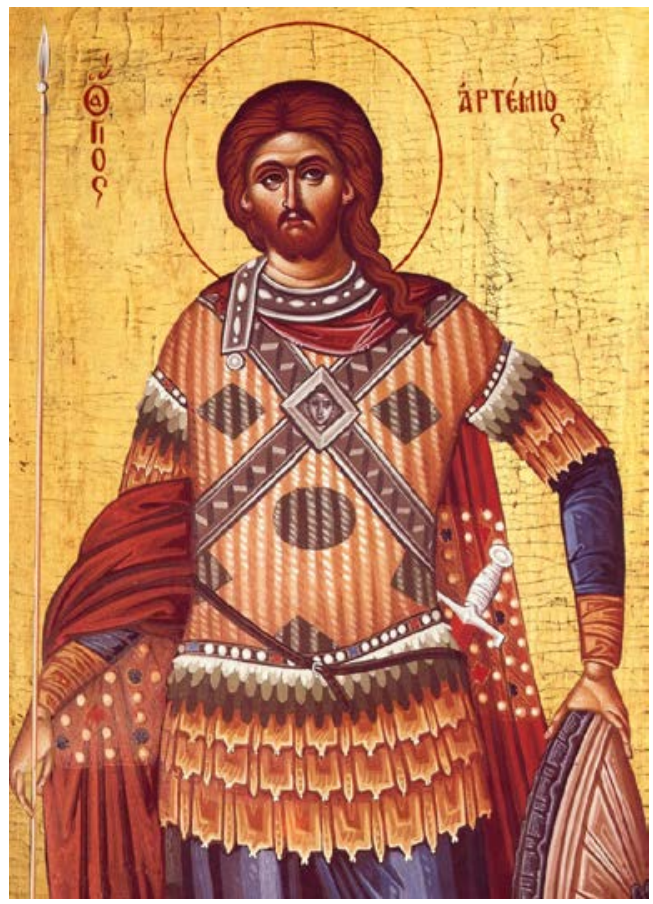

Figure 2: Orthodox icon of Saint Artemius, Great Martyr of Antioch.

members to the new religion. ${ }^{46,47}$ "The Miracles of St. Artemius", a text which records forty-five cures, mainly of scrotal hernias and disorders of the male genitals, aged one month to 25 years, took place at an incubation center in seventh-century Constantinople, did not require a reward. Children were healed after Saint Artemius appeared in their parents' dreams. For example, in the first miracle, the physician Anthimus took his son, who had severe testicular pain to the shrine of Saint Artemius. The son dreamed that Artemius (in the form of his father) squeezed his testicles, and when he awoke, the pain was gone. In another case (miracle 28), the mother of a child suffering from enterocele dreamed of Saint Artemius grabbing her child by the foot. The next morning, the mother found her child completely cured. Rational explanations for these miracle cures might be a spontaneous reduction of testicular torsion or a scrotal hernia. ${ }^{48}$

The most relevant reference to protectors saints is the one about $\mathrm{S}$. Theodosius from Athens (7/8/862 AD). He not only appeared but performed the incision at the site of laryngitis or diptheritis, on the voiceless child's neck, pus leaked out along with the blood, and the voice was restored to normal. ${ }^{49}$

46 Calofonos, G.T. (2007), Disease and Corporeality in Early Byzantium: The Miracles of St. Artemios, Archaeology, 103, 42-49.

47 Drampalos, E., Stogiannos, V., Psyllakis, P., Sadiq, M., Michos, I. (2014), The influence of theory on the formation of the infirmary during antiquity and the Middle Ages in the West, J Med Ethics Hist Med, 7, 21.

48 Poulakou-Rebelakou, E. (1992), Pediatric practice during Byzantine times, Doctoral Thesis, National $\mathbb{E}$ Kapodistrian University of Athens, Greece, 62.

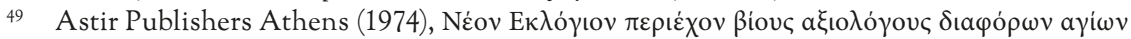

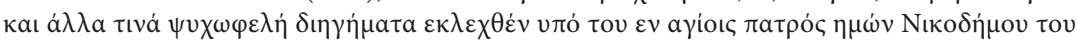

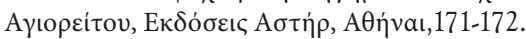




\section{Discussion - CONCLUSIONS}

During the Byzantine period, healing methods were common for both adults and children.

The lack of anesthesia and antisepsis made the surgical procedure a frightening experience, especially for the pediatric population.

The problem of the Byzantine people, when an operation was necessary, and there was no way to avoid it, seemed to find a solution at the shrines of some miraculous Healer Saints. St Artemius, as recorded in the Miracula of St Artemii, was specialized in urogenital cases demanding operation and was very effective and successful in treating without surgery. Hernias, infections, and traumas of the genitalia were the usual problems he faced. In spite of these facts, the 3 Byzantine surgeons marked the beginning of a new era for pediatric surgery, and their medical approach to it endured for centuries to come.

European and Arab medicine is highly influenced by their work, and many medical issues are managed nowadays, surprisingly identically with the way they were confronted in the Byzantine era.

\section{REFERENCES}

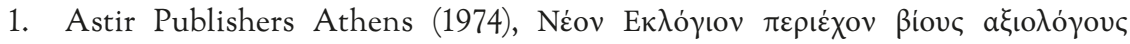

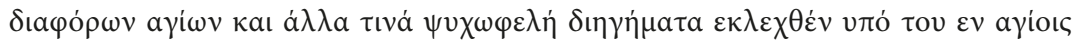

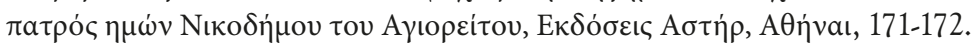

2. Bliquez, LJ. (1984), Two lists of Surgical Instruments and the State of Surgery in Byzantine Times, Dumbarton Oaks Papers, (ed.) J. Scanborough, 187-204.

3. Briau, R.M. (1855), Chirurgie de Paul d' Égine, Paris; Masson, 330-331.

4. Calofonos, G.T. (2007), Disease and Corporeality in Early Byzantium: The Miracles of St. Artemios, Archaeology, 103, 42-49.

5. Carter, A.J. (1996), Narcosis and nightshade, British Medical J., 313, 1630-1632.

6. De Moulin, D. (1988), A history of Surgery, Dordrecht/Boston/Lancaster; Martinus Nijhoff, 24.

7. Drampalos, E., Stogiannos, V., Psyllakis, P., Sadiq, M., Michos, I. (2014), The influence of theory on the formation of the infirmary during antiquity and the Middle Ages in the West, J Med Ethics Hist Med, 7, 21.

8. Durmont, D.S. \& Smith, RM. (1992a), Aeginitis P. Epitomae medicae libri septem, California; Thesaurus Linguae Greacae [CD ROM]. CD ROM Musaios, Book 6, Chapter 3, Section 26. 
9. Durmont, D.S., \& Smith, R.M. (1992b15). Amideni Aetii. Iatricorum Liber, California; Thesaurus Linguae Greacae [CD ROM]. CD ROM Musaios, Book 15, Chapter 22, Section 14.

10. Durmont, D.S. \& Smith, R.M. $\left(1992 b^{2}\right)$, Amideni Aetii. Iatricorum Liber, California; Thesaurus Linguae Greacae [CD ROM]. CD ROM Musaios, Book 15, Chapter 12, Section 26.

11. Durmont, D.S. \& Smith, R.M. (1992c), Orivasios. Collectiones medicae, California; Thesaurus Linguae Greacae [CD ROM] CD ROM Musaios, Book 46, Chapter 28, Section 6.2.

12. Grimaud, J.C., Munoz-Bongrand, N., Siproudhis, L. Abramowitz, L., Sénéjoux, A., Vitton, V., Gambiez, L., Flourié, B., Hébuterne, X., Louis, E., Coffin, B., De Parades, V., Savoye, G., Soulé, J.C., Bouhnik, Y., Colombel, J.F., Contou, J.F., François, Y., Mary, J.Y., Lémann, M. (2010), Fibrin glue is effective healing perianal fistulas in patients with Crohn's disease, Gastroenterology, 138, 2275-2281.

13. Grosfeld, J., O’Neill, J.A., Forkalsrud, E. \& Coran, A. (2006), Paediatric Surgery $6^{\mathrm{TH}}$ edition, Saint Louis; Mosby, 1597.

14. Gurunluoglu, R., Gurunluoglu, A. (2001), Paulus Aegineta, a seventh century encyclopedist and surgeon: his role in the history of plastic surgery, Plast Reconstr Surg., 108(7), 2072-9.

15. Harley, R.D., Nelson, L.B., \& Olitsky, S.E. (2005), Harley's Pediatric Ophthalmology, Philadelphia; Lippincott Williams \& Wilkins, 553.

16. Hernam, JR. (1915), Urology. A View Through the Retrospectoscope, Maryland: Harper \& Row.

17. Lascaratos, J., Kostakopoulos, A. \& Louras, G. (1999), Penile surgical techniques described by Oribasius (4th century CE), British Journal of Urology, 84, $16-19$.

18. Lascaratos, J., Lascaratos, G., Kostakopoulos, A. (2004), Surgical confrontation of urolithiasis in Byzantium, UROLOGY ELSEVIER INC, 63, 806-809.

19. Lascaratos, J.G., Panourias, I.G., Sakas, D.E. (2004), Hydrocephalus according to Byzantine writers, Neurosurgery, 55(1), 214-20; discussion 220-1.

20. Laskaratos, J.G., Tsiamis, C. \& Kostakis, A. (2003), Surgery for inguinal hernia in Byzantine times (A.D. 324-1453): first scientific descriptions, World Journal of Surgery, 27 (10), 1165-1169.

21. Mentis, A.F., Kararizou, E. (2011), The dialectic relationship between medicine and miracles in the Eastern Christian Roman Empire, Archives of Hellenic Medicine, 28(4), 561-568.

22. Miller, T.S. (1984), Symposium on Byzantine Medicine, Dumbarton Oaks Papers, (ed.) J. Scanborough, Trustees for Harvard University, 38, 53-63.

23. Milne, J.S. (1976), Surgical instruments in Greek and Roman times, Chicago; Ares Publishers, 28-46, 94-7. 
24. Missios, S., Bekelis, K., Roberts, D. (2014), Neurosurgery in the Byzantine Empire: The contributions of Paul of Aegina (625-690 AD), J Neurosurg, 120, 244-249.

25. Nutton, V. (1984), From Galen to Alexander, Aspects of Medicine \& Medical Practice in Late Antiquity, Dumbarton Oaks Papers, (ed.) J. Scanborough, 38, 1-14.

26. Papadakis, M., de Bree, E., Trompoukis, C., Manios, A. (2018), Paul of Aegina's surgical instruments: a complete surgical instrumentarium in the seventh century AD, ANZ J Surg, 88(7-8), 779-785.

27. Papadakis, M., Manios, A., Trompoukis, C. (2019), Surgical treatment of polydactyly and syndactyly during the 4th century AD, Acta Chir Belg., 119(1), 64-65.

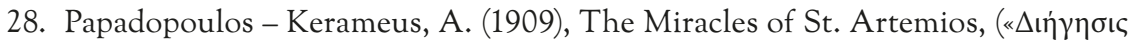

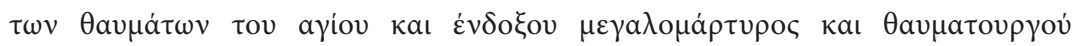
A $\tau \tau \varepsilon$ íov.»), St. Petersburg, 1-75.

29. Pedanii, Dioscorides. (1958), De Materia Medica, $1^{\text {st }}$ edition. Berlin; Max Wellmann.

30. Pormann, P. (2004), The Oriental Tradition Paul of Aegina's Pragmateia, Oxford; Brill Academic.

31. Poulakou-Rebelakou, E. (2000), Pediatric practice during Byzantine times, Archives of Hellenic Medicine, 17(3), 326-331.

32. Poulakou-Rebelakou, E. (1992), Pediatric practice during Byzantine times, Doctoral Thesis, National $\mathscr{Z}$ Kapodistrian University of Athens, Greece, 62.

33. Raeder, I. (1933), Oribasii collectionum medicarum reliqviae, vol. IV, Lipsiae et Berolini; Teubner, 55-62.

35. Raffensperger, J.G. (2012), Children's Surgery: A Worldwide History, Jefferson / North Carolina; McFarland \& Company, 48.

36. Ramoutsaki, I.A., Dimitriou, E., \& Kalmanti, M. (2002) Management of childhood diseases in the Byzantine period: I - Analgesia, Pediatrics International, 44, 335-337.

37. Read, R.C. (1984), The development of inguinal herniorrhaphy, Surgical Clinics of North America, 64, 185-196.

38. Scanborough, J. (1984), Symposium on Byzantine Medicine: Introduction, Dumbarton Oaks Papers, (ed.) J. Scanborough, p. IX-XVI.

39. Shah, J., Whitfield, H.N. (2002), Urolithiasis through the ages, BJU Int., 89, 801-810.

40. Skoulakis, CE., Manios, AG., Theos, EA., Papadakis, CE., Stavroulaki, PS., (2008), Treatment of nasal fractures by Paul of Aegina, Otolaryngol Head Neck Surg, 138(3), 279-82. 
41. Tsoucalas, G. \& Sgantzos, M. (2016), Paul of Aegina (c. 625-690 AD), the Origins of the Early Correction of Pediatric Strabismus in Byzantine Empire, Strabismus, 24(3), 136-7.

42. Tsoucalas, G., Gentimi, F., Kousoulis, A.A., Karamanou, M., \& Androutsos, G. (2012), Imperforate anus and perianal fistula in Ancient Greek medical writings, Annals of Gastroenterology, 25(3), 241-242.

43. Tsoucalas, G., Laios, K., Sgantzos, M., Androutsos, G. (2016), Paul of Aegina (c. 7th Century AD): Introducing in the Surgical Operating Theatre of the Era an Innovative Tonsillectomy with a Forceps Under the Sunlight, Surg Innov, 23(1), $102-3$.

44. Tsoucalas, G., Papaioannou, T., Karamanou, M. (2018), Michael Constantine Psellus (1020-1105 AD) and his definition of strabismus, Strabismus, 26(3), 155-157.

45. Tsoucalas, G., Sgantzos, M. (2017), Paul of Aegina (ca 625-690 AD), and his orthopaedic surgical reconstruction of the preternatural fingers, Int Orthop., 41(1), 211-216.

46. Tsoucalas, I. (2004), Paediatrics From Antiquity Until the Modern Era, Athens, Greece: Science Press, 778-181.

47. Zervos, S. (1909), Aetius, Iatricorum Liber XV, Athens; 21, 7-138.

\section{SAŽETAK}

U bizantsko doba medicina i kirurgija razvijali su se dok su grčki liječnici nastavili s praksom u Carigradu. Metode liječenja $i$ za odrasle $i$ za djecu se nisu razlikovale, a pedijatrija kao medicinska specijalizacija nije postojala.

Bizantske bolnice postale su ustanove, a ne skloništa za beskućnike, u kojima su liječnici i medicinske sestre pružali medicinske usluge za sve oboljele. $U$ ovom se razdoblju dogodilo veliko poboljšanje statusa bolnica kao medicinskih centara, a liječnici su prozvani archiatroi. Nekoliko izvora dokazuje da su archiatroi još uvijek djelovali u kasnom šestom stoljeću i dugo nakon toga, ali sada kao ksenonski liječnici.

Pacijenti nisu bili skloni operacijama zbog učestalosti komplikacija. U hagiografskoj literaturi su se učestalo spominjali liječnici. Zabrinutost za djecu s kirurškom bolešću roditelje je često tjerala da traže čudesna ozdravljenja koja su prakticirali kršćanski sveci zaštitnici.

Ovaj rad govori o tri ugledna bizantska liječnika i kirurga. Oribazije, Aecije iz Amide $i$ Pavao iz Aegine bavili su se pedijatrijskim operacijama i utjecali na europsku medicinu u idućim stoljećima.

Proučavali smo povijesne i teološke izvore kako bismo predstavili sveobuhvatnu sliku kurativnih tehnika koje su korištene za dječje kirurške bolesti u bizantsko doba.

Ključne riječi: povijest Bizanta, dječja kirurgija, sveci zaštitnici 